\title{
NOTES ON THE EPIPHARYNX, AND THE EPIPHARYNGEAL ORGANS OF TASTE IN MANDIBULATE INSECTS.
}

\author{
BY ALPHEUS SPRING PACKARD., PROVIDENCE, R. I.
}

Réaumur was, so far as we have been able to ascertain, the first author to describe and figure the epipharynx, which he observed in the honey bee and bumble bee, and calls la langue, remarking that it closes the opening into the oesophagus, and that it is applied against the palate. ${ }^{1}$ According to Kirby and Spence, ${ }^{2}$ DeGeer ${ }^{8}$ described the epipharynx of the wasp: and Latreille ${ }^{4}$ referred to it, calling it the sous labre.

The name epipharynx was bestowed upon this organ by Savigny, ${ }^{5}$ who thus speaks of that of the bees: Ce pharynx est, à la vérité, non-seulement caché par la lèvre supérieure, mais encore exactement recouvert par un organe particulier que Réaumur a déjà décrit. C'est une sorte d'appendice membraneux qui est reçu entre les deux branches des mâchoires. Cette partie ayant pour base le bord supérieur du pharynx, peut prendre le nom d'épipharynx ou d'épiglosse.

$\mathrm{He}$ also describes that of diptera

\footnotetext{
${ }^{1}$ Réaumur, Mémoires pour servir a l'histoire des insectes, v. 5, I740, p. 31S. pl. 28, figs. $4,7,8,9$, 10, 1 i $l$.

${ }^{2}$ Kirby and Spence, Intr. to entomology, v. 3, 1828, p. 457

3De Geer, v. 2, 1778-v. 26, fig. I1. M. (Kirby and Spence, pl. xii. fig. $2 \mathrm{~K}$.)

${ }^{4}$ Latreille, Organization extérieure des Insectes, p. 184. (Quoted from Kirby and Spence.)

5Savigny. Mémoires sur les animaux sans vertèbres. Partie rre, 1816, p. 12.
}

What Walter ${ }^{6}$ has lately proved to be the epipharynx of lepidoptera, was regarded by Savigny and all subsequent writers as the labrum.

The latest account of the function of this organ is that by Cheshire, who states that the tube made by the maxillae and labial palpi cannot act as a suction pipe, because it is open above. "This opening is closed by the front extension of the epipharynx which closes down to the maxillae, fitting exactly into the space they leave uncovered, and thus the tube is completed from their termination to the oesophagus."

It is singular that this organ is not mentioned in Burmeister's Manual of entomology, in Lacordaire's Introduction à l'entomology, or by Newport in his admirable article Insecta in 'Todd's Cyclopedia of anatomy.

Neither has Straus-Durckheim referred to or figured it in his great work on the anatomy of Melolontha vulgaris. ${ }^{8}$

In their excellent work on the Cockroach, Miall and Denny state that "The epipharynx, which is a prominent part

${ }^{6}$ Walter, Alfred, Beitge zur morphologie der schmetterlinge. Erster thel. Zur morphologie der schmetterlingsmundtheile. (Jena. Zeits., v. 18, 1885, p. 752.)

${ }^{7}$ Cheshire. Bees and bee-keeping. I. London, 1886, p. 93 .

8 Considérations générales sur l'anatomie comparée des animaux articulés, 1828 . 
in coleoptera and diptera, is not recognizable in orthoptera." (p. 45.)

I am not aware that any modern writers have described or referred to the epipharynx of the mandibulate orders of insects, though I must confess that I have not made extended search after such references and I would be thankful for information and references. Although Dr. G. Joseph ${ }^{9}$ speaks of finding them on the palate of almost every order of insects, especially plant-feeding forms, we are unable to find any specific refererences, his detailed observations being apparently unpublished.

The epipharnyx is so intimately associated with the elongated labium of certain diptera, that, with Dr. Dimmock, ${ }^{10}$ we may, refer to the double organ as the labrum-epipharynx; and where, as in the lepidopterous Microp. teryx semipurpurella, described and figured by Walter, ${ }^{11}$ and the panorpi$d a e^{12}$ (Panorpa and Boreus), the labrum seems pieced out with a thin, pale, membranous fold which appears to bean extension of the epipharynx, build ing up the dorsal end of the labrum, this term is a convenient one to use.

In the lower orders of truly mandibulate insects, from the thysanura to the coleoptera, excluding those which suck in liquid food, such as the diptera, lepi-

\footnotetext{
9 Joseph, Gust, Zur morphologie des geschmacksoganes bei inseckten. Amtlicher bericht der 50 ver $r$ sammlung deutscher naturforscher u. Artzte in München. 1877, p. 227-228.

${ }^{10}$ Dimmock, George. The anatomy of the mouthparts and of the sucking apparatus of some diptera s $88 \mathrm{r}$.

11 Op. cit., fig. 3

12 Packard, A. S. Psyche, 1889, v. 5, p. 159-164.
}

doptera and hymenoptera, and the mecaptera (Panorpidae) with their elongated head and feeble, small mandibles; the epipharynx forms a simple membranous palatal lining of the clypeus and labrum. It is not, so far as we have observed in any mandibulate insects in which the mouth parts are free, adapted for mastication only, the mandibles being well developed,-in such insects there is no soft projecting or pendant portion, fitted to close the throat or to complete a partially tubular arrangement of the first and second maxillae.

In all the forms, then, described below, the epipharynx forms simply the under surface or pharyngeal lining of clypeus and labrum, the surface being uniformly moderately convex, and corresponding in extent to that of the clypeus and labrum, posteriorly merging into the palatal wall of the pharynx; the armature of peculiar gathering-hairs sometimes spreading orer its base, being continuous with those lining the mouth and beginning of the oesophagus. The suture separating the labrum from the clypeus does not involve the epipharynx, though since certain gustatory fields lie under the front edge of the clypeus, as well as labrum, we may in describing them refer to certain fields or groups of cups or pits as occupying a labral or clypeal region or position.

In our descriptions we have called attention to the shape of the front edge of the labrum, whether notched or not, and whether bearing traces of a median suture, on account of the bearing of these parts on the question whether the labrum 
represents a first pair of antennae. The lack of traces of a suture in the epipharynx corresponding to the labral suture above, suggests that the labrum does not represent a pair of coalesced appendages, and that it, with the clypeus, simply forms the solid epidermal roof of the mouth.

The only soft structures seen between the epipharynx and labrum besides the nerves of special sense, are the elevator muscles of the labrum and two tracheae, one on each side.

The structure and armature of the epipharyngeal surface even, besides the taste-pits, cups and rods, is unexpectedly varied, the setae assuming very different shapes. There seems to be two primary forms of setae, (I), the normal forms which arise from a definite cell, the setae being a hypertrophied nucleus, as first shown by Newport, and (2), soft, flattened, often hooked hairs which are cylindrical toward the end, but arise from a broad triangular base, without any cell-wall, not arising from distinct nuclei. These are like the gathering hairs (Cheshire) on the bee's and wasp's tongue; they also line the walls of the pharynx and extend toward the oesophagus. They are the "hooked hairs" of Will. The first kind or normal setae are either simply defensive, often guarding the sense-cups or sensory fields, or they have a nerve extending to the $m$ and are tactile.

It will be seen by the following descriptions that in the thysanura no true gustatory cups or pits have been found; and that immature dermaptera are des- titute of them. On the other hand taste. cups occur on the epipharynx of the larvae of longicorn, scarabaeid and buprestid beetles, and they are as abundantly developed in carabid or carnivorous beetles as in plant-eating coleoptera. Also, within the limits of a family like the locustidae they are less abundant in one of the more generalized genera as Xiphidium, and more numerous in a highly specialized genus, as Cyrtophyllus.

I should say that I have examined the taste-cups of the honey bee, finding that they agree with Wolff's figures, and that those of insects of the orders described below are essentially of the same structure and all seem by situation to be gustatory in function.

\section{Order J'hysanura.}

Lepisma sp. from Havana. - The specimen examined was one of a number kindly collected for me by the venerable Professor Poey of Havana in his own house. The labrum is slightly excavated along the entire margin, but there is no trace of a median suture; and over the surface, are scattered long acute hairs, while at the base and over the clypeus are thickly planted, singular long setae which are hairy beyond the middle, and are forked at the end.

The epipharynx ends in front in a broad median lobe somewhat as in Forficula, the edge of which bears numerous very short cylindrical rods, whose presence can only be distinctly made out by a power of 400 diameters. This lobe is also covered with an exceedingly 
fine pile consisting of acutely lanceolate hairs arising from a broad, non-nucleated base; those on the sides, especially in front, being directed towards the middle of the epipharynx, and much coarser than those situated farther back.

There is no median furrow, and no sense-pits, cups or rods, the median region being clothed with fine hairs.

Machilis variabilis Say.-The shape of the labrum and epipharynx is very singular. The labrum is narrower than long, the front edge slightly excavated, and provided with a row of short, stiff, broad, flat setae, which end in a short fork. There are no traces of a median suture.

The epipharynx has no separate median frontal lobe like that of Lepisma, but the broad edge simply forms the under surface of the labrum. The edge is provided with a singular armature of about four rows of short thick appressed spines, whose ends turn down a little, so that they appear like four rows of somewhat polygonal paving stones; each has a central nucleus. I can perceive no setae arising from them. Whether these singular shortened and curved rods are gustatory, or in any way sensory, or whether simply defensive, remains to be proved; I could not detect any nerves leading to them. From each side of the end of the epipharynx two series, in oblique rows, of somewhat appressed, rather large, short conical setae, with a nucleus at the end, curve inwards along the distal third of the epipharynx, and thence extend parallel to each other towards the base of the epipharynx. Of these conical setae, those in front when examined with a power of 400 diameters do not appear to bear a bristle, though there is a nucleus at the end; but many of those situated farther back bear a long acute bristle. There is no median furrow, but the median region is very finely pilose, the fine hairs becoming more numerous at the base and extending along the epipharyngeal lining of the clypeus. No genuine sense-pits, cups or rods could be detected.

\section{Order Dermaptera.}

Forficula sp. from Cordova, Mexico. - The labrum is rounded in front with no traces of a median suture.

Epipharynx with a membranous edge in front, fringed with a dense row of short fine setae, and just within the edge are two or three rows of sinuous, slender, blunt setae, of peculiar shape, which may be possibly gustatory. The surface is covered with very fine scale-like setae, and on each side near the base is a region covered by a short dense pile.

The taste-pits are few in number, there being only about a dozen on each side in all; most of them being situated on the anterior half, and a few near the base. The taste-pits are provided each with a short fine seta, as usual, arising from the centre.

Forficula larva from Florida. The front edge of the labrum is entire, rounded, and there are no traces of a median suture. The front edge of the epipharynx forms a slight projection or lobe, about half as wide as the labrum, which is fringed with fine setae, some 
of which are hair-like, acute, while others are blunt and curved. The surface in general is covered with the usual fine pile. The median area is bordered by a pile-covered area, but along this region no sense-pits, cups, or rods could be detected with a power of 400 diameters; over the region where they usually occur were to ke seen scattered conical setae.

\section{Order Orthoptera.}

$A$ wingless Blattid from Florida. -The labrum is full and rounded on the front edge, with no indications of a median suture. The surface of the epipharynx is finely and densely pilose. There are no sense pits, cups or rods visible.

Blatta, a large winged species from Cuba. - Front of the labrum slightly excavated. The epipharynx is provided on the front edge with very numerous short, stout, minute setae, which are curved downward, and form when looked at vertically, a pavement-like mass; beyond on the extreme edge is a dense fringe of short slender rod-like bristles. The surface elsewhere is finely pilose, the median region not being bare. On each side of the middle is a curved row of stiff defensive spines; at the distal end of each row is a sensitive field, containing 20 taste-cups on one side and 23 on the other. Near the front edge of the clypeal region are two more sense-fields, situated on each side of the median line, there being 35 taste-cups in each field. The taste-cups in this species are rather smaller than usual.
Spectrum bivittatum Say. - In a specimen from Indian River, Fla. the front edge of the labrum is entire, but along the middle are traces of a median suture. The middle region of the epipharynx, and the epipharyngeal lining of the clypeus are covered with fine and coarse setae, but there is no bare space, and no sense-pits are to be detected. (Those that at first appear to be such are ordinary cells with the setae broken off.)

Camnula pellucida Scudd.-The labrum is notched, but the edge is plain, not bearing any rods or bristles on the border of the excavation, or elsewhere on the labral margin. There is a well defined short median suture in the middle of the labrum which sends posteriorly two forks.

The epipharynx is free from hairs along the middle, and near what corresponds to the front edge of the clypeus, are two sensitive fields, each containing about 35 taste-pits. Just in front under the suture between the clypeus and labrum are two similar fields, each containing from 40 to 42 taste-pits. There are none in front of these.

Xiphidium brevipennis Scudd. 9 . -The epipharynx is slightly notched at the end in the middle and the sinus filled with slender setae. The median line forms a slight furrow, while the surface of the epipharynx in general is covered with fine rather stiff short setae.

Along each side of the median line on the anterior half of the epipharynx are scattered about 30 taste-cups, mostly without, but some bearing rather large and long setae. At the base is a scat- 
tered group of seven taste-cups on each side of the base of the median furrow, nearly all bearing a bristle, but some not; all are so isolated from the other true hairs that they are most probably gustatory. On each side of the region corresponding to the front edge of the clypeus is a group of ahout 30 tastecups, only one or two of the outer ones of which seem to bear a bristle.

Cyrtophyllus. concavus Scudd.-End of the labrum notched and the sinus filled in with stiff blunt bristles, this area extended back on the epipharynx; there are distinct traces of a median suture. Along the middle of the epipharynx the spines are absent. The taste-cups are arranged much as in Xiphidium, but they are more numerous, as might be expected, this genus being in general the more specialized. There are from $5^{\circ}$ to 60 taste-cups in the front region; behind the middle a group of 25 on each side, and over an area corresponding to the base of the labrum and front edge of the clypeus is a sensory field with about 70 taste-cups on each side. They are true cups or beaker-like papillae, some with a fine, others with a short, stout, conical seta. The katydid is thus provided with about I 70 to I8o taste-cups on its epipharynx.

Anabrus simplex Hald.-Front edge of the labrum full, though there are traces of a median suture. The surface of the epipharynx is covered with stout setae. Along the median furrow of the epipharynx which is bordered with a delicate pile, are scattered, especially near the base, a few peculiar taste-cups, each bearing a very short conical seta, which is larger and shorter than usual the furrow not being pilose. At a point situated near the anterior edge of the clypeus the heavy spines towards the middle graduate into what appear to be sense-cups.

Ceuthophilus maculatus (Harris).Labrum slightly excavated. Surface of the epipharynx finely pilose. Front edge at the middle forming a highly specialized pilose area, excavated on the edge, the sinus being broad and shallow and the edge lined with a hedge-like row of close-set gustatory rods. A well marked median furrow, free from hairs or bristles, and in front is a group, 30 on each side of the median line, of raised papillae-like taste-cups, a little sh orter and broader than those of Hadenoecus. At the base of the labral region on each side of the median line is a sensory field of 25 taste-cups arranged in quite regular rows. On the anterior clypeal region is a group of 9 or io scattered taste-cups which are shorter, more like cups and far less numerous than in Hadenoecus.

Hadcnoecus subterraneus Scudd.In specimens from White's Cave near Mammoth Cave, Ky., the front edge of the labrum is peculiar from the very deep, narrow median pouch-like sinus, which enlarges towards the bottom, and opens out on a median projection, which, as well as the sinus, is fringed with coarse spines, which at the mouth of the sinus become curved. The tastecups are highly developed in this cavecricket, being rounded papillae with the 
nucleus at the top or end. They are grouped on each side of the middle near the front edge, there being 25 on each side. An irregular row of these cups extends along each side, some occur under the base of the labrum, but they are most numerous on a field corresponding to the front edge of the clypeus, there being 50 on each side, or 100 in all, where in Ceuthophilus there are only 9 or io.

The gustatory cups being so much longer, better developed and much more numerous in the cave Hadenoecus than in Ceuthophilus, which lives under stones, etc., out-of-doors, it would seem as if the sense of taste were much more acute in the cave-dweller than the outof-doors form, though it does live for the most part in twilight.

Conocephalus ensiger Harris, 9.The epipharynx is full in front, with a deep, narrow, median furrow or gutter along which the liquids probably pass into the throat. At the end is a fringe of fine bristles. On the clypeal region there are about 25 taste-cups, a few projecting over the edge of the gutter; a few more are scattered along the gutter to near the end of the labrum.

Gryllus sp.-In the common black cricket the labrum is rounded in front with a median excavation, the sinus being fringed with rather long, stout, flat, truncated setae, which are longer on the sides than in the middle. There are traces of a longitudinal suture.

The surface of the epipharynx is covered towards the front with fine hairs; on the sides in front are large coarse spines, and at the base is a large area covered with coarse, defensive spines, directed inwards towards the median furrow, which is free from setae.

Taste-cups are abundant; in front, at some distance from the front edge is on each side a group of conical rounded cup-like papillae, carrying the nucleus at the top, there being about 30 arranged in four very regular rows. Nearer the middle is a group, on each side of the middle of the furrow, of 8 taste-cups which are situated just in front of the ends of two curved tracheae. On the outside of the tracheae is a linear group of about 60 taste-cups extending from the base to near the isolated group of 8 cups. Another sensory field containing 45 taste-cups on each side of the median line, or $9^{\circ}$ in all, scattered over the area, is situated under the nose of the labrum and front edge of the clypeus, most of them behind the labrum. There is also a lateral group of about I 4 taste-cups on the outer edge on the front region of the clypeus and situated outside of the base of the curved tracheae. The sides of the epipharynx under the clypeus are clothed with fine "gathering" or " hooked hairs."

Oecanthus nivous Serville $9 .-$ The shape of the labrum and epipharynx, as well as the number and distribution of the taste-cups, are almost exactly as described in Conocephalus ensiger.

( $T o$ be continued.) 

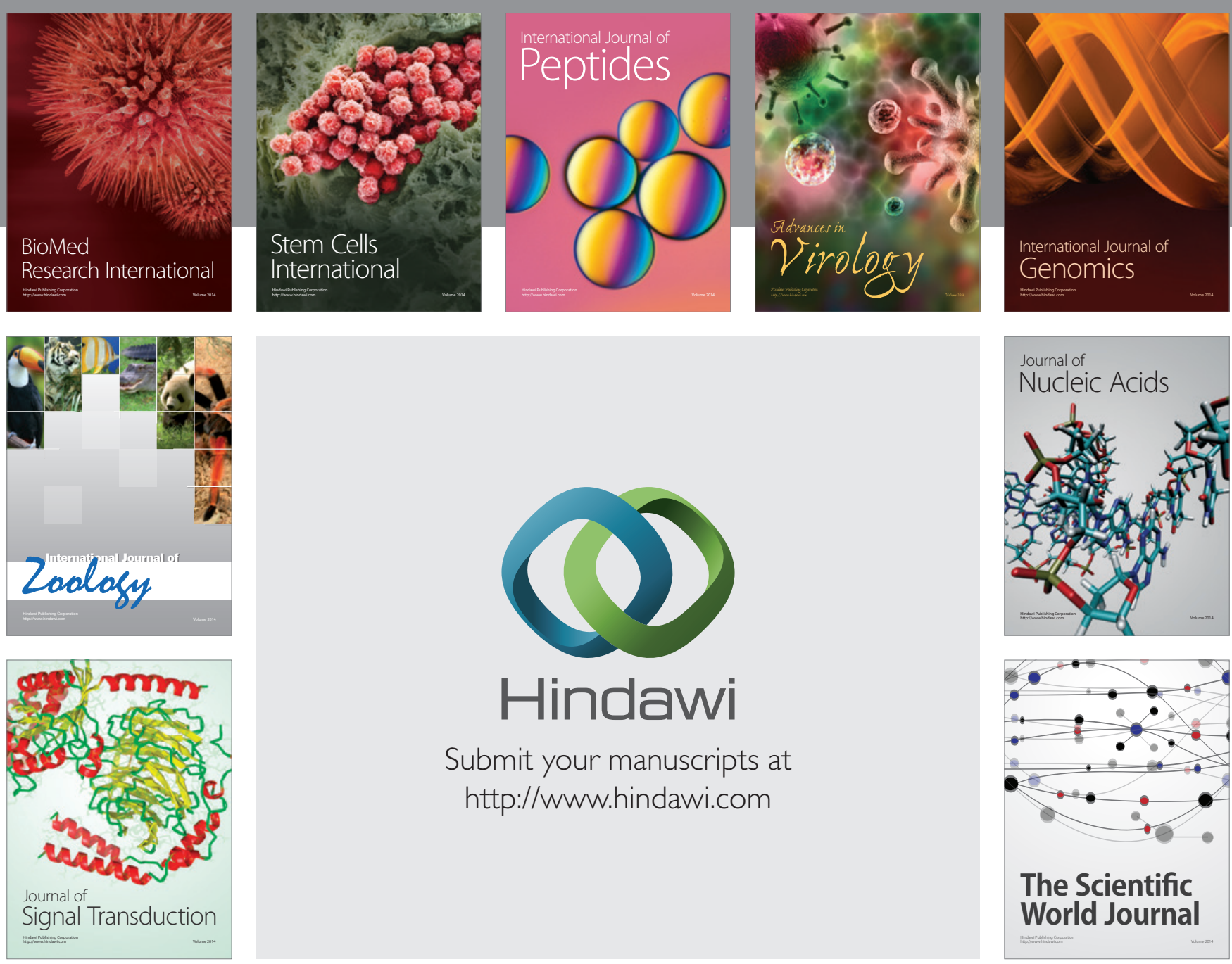

Submit your manuscripts at

http://www.hindawi.com
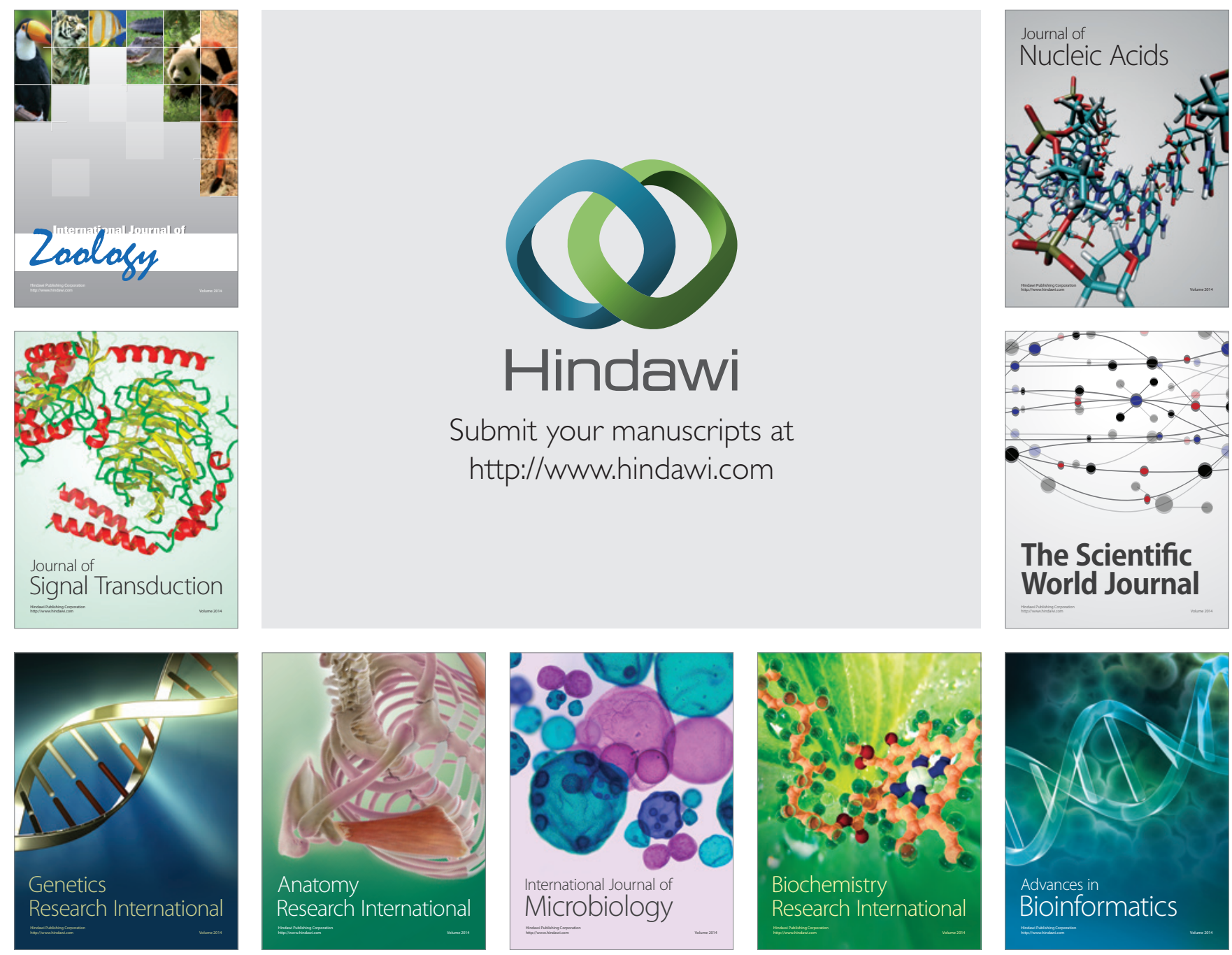

The Scientific World Journal
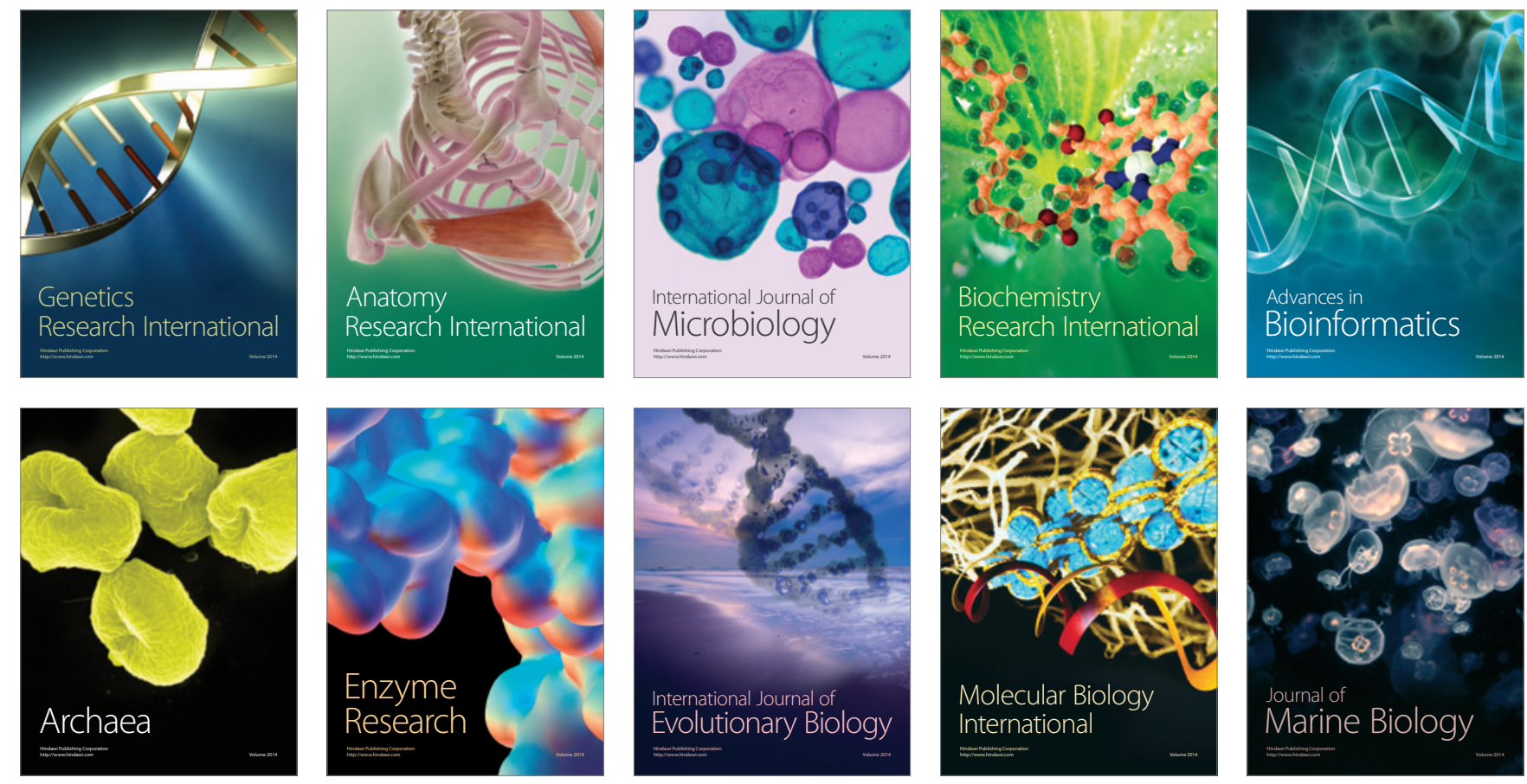